\title{
Microdissecção e captura a laser na investigação do gene TP53 em tecidos incluidos em parafina
}

\author{
Laser-capture microdissection for TP53 gene analysis in paraffin-embedded tissues
}

Shadia Muhammad Ihlaseh', Maria Luiza Cotrim Sartor de Oliveira ${ }^{2}$, Glenda Nicioli da Silva ${ }^{3}$, Carla Adriene da Silva Franchi ${ }^{4}$, João Lauro Viana de Camargo ${ }^{5}$

\begin{abstract}
unitermos
Microdissecção e captura a laser

Extração de DNA

Nested-PCR

Gene TP53

Gene ciclofilina

Blocos de parafina

\section{resumo}

Introdução: Microdissecção e captura a laser (MCL) é uma técnica de desenvolvimento recente que permite a coleta de células individuais ou pequeno conjunto de células para análise molecular. Atualmente, no Brasil, há raros microscópios para $\mathrm{MCL}$, de modo que a divulgação dos procedimentos inerentes a essa técnica é oportuna para destacar seu amplo potencial para diagnóstico e investigação. Objetivo: Este trabalho descreve a padronização dos procedimentos de MCL e de extração de DNA de material fixado em formalina e incluído em parafina. Material e métodos: Foram estudados o éxon 8 do gene TP53 e o gene da ciclofilina em amostras de tecido normal e de neoplasias de fígado e rim provenientes de modelo de carcinogênese química induzida em rato. A extração do DNA foi comprovada por reação em cadeia da polimerase (nested-PCR). Resultados: Foram padronizados os procedimentos de preparo dos cortes histológicos, de microdissecção e captura a laser e de obtenção de seqüências gênicas pela reação de nested-PCR para tecidos incluídos em parafina. Obtivemos amplificação de $48,3 \%$ das amostras para o éxon 8 do gene TP53 e 51,7\% para o gene da ciclofilina. Considerando pelo menos um dos dois segmentos gênicos, foram amplificadas 79,3\% das amostras. Discussão e conclusão: A extração de DNA de tecidos fixados em formalina e incluídos em parafina e a técnica de nested-PCR foram adequadamente padronizadas para produtos gênicos de interesse, obtidos de material coletado por MCL. Esses procedimentos podem ser úteis para a obtenção de seqüências de DNA de arquivos para análise molecular.
\end{abstract}

abstract

Background: Laser-capture micro-dissection (LCM) is a recently developed procedure that provides single cells or specific cell groups for molecular analysis. Currently, there are few LCM systems in Brazil, in such a way that it is necessary to disseminate the technical procedures inherent to the methodology, and also to characterize its enormous potential for diagnosis and research. Objective: This study describes the standardization of LCM and DNA extraction from formalin fixed and paraffin-embedded tissues. Material and Method: The gene TP53 exon 8 and the cyclophilin gene were studied in normal and neoplastic liver and kidney samples from a chemical carcinogenesis model in rat. DNA extraction was confirmed by nested-PCR. Results: Histological sections preparation for LCM and the nested-PCR procedures were standardized; $48.3 \%$ amplifications of the gene TP5 3 exon 8 and $51.7 \%$ of the cyclophilin gene samples were obtained. When at least one of the gene segments was considered, $79.3 \%$ samples presented amplification. Discussion and Conclusion: Procedures for DNA extraction from formalin fixed and paraffin-embedded tissues collected by LCM were standardized. They can be useful for DNA collection for molecular studies.

\section{key words}

Laser-capture microdissection

DNA extraction

nested.PCR

TP53 Gene

Ciclophilin gene

Paraffin-embedded tissues

1. Mestranda do Departamento de Patologia da Faculdade de Medicina de Botucatu, Universidade Estadual Paulista (FMB/Unesp).

2. Bióloga; Doutora pelo Departamento de Patologia da FMB/Unesp.

3. Doutoranda pelo Departamento de Patologia da FMB/Unesp.

4. Médica veterinária; Doutora pelo Departamento de Patologia da FMB/Unesp.

5. Professor-titular de Patologia do Departamento de Patologia da FMB/Unesp.

Trabalho desenvolvido no Departamento de Patologia da FMB/Unesp como monografia de graduação da biomédica Shadia Muhammad Ihlaseh.

Auxilios: Conselho Nacional de Desenvolvimento Científico e Tecnológico (CNPq), processos 501776/04-4 (bolsa de iniciação científica) e 302361/2003 (bolsa de produtividade em pesquisa);

Núcleo de Avaliação do Impacto Ambiental sobre a Saúde Humana (Toxicam). 


\section{Introdução}

A microdissecção e captura a laser (MCL) é uma técnica de desenvolvimento relativamente recente que permite a obtenção de amostras de tecidos normais ou alterados, ou de células individuais de regiões microscópicas específicas ${ }^{(18)}$. O contato com o laser preserva a morfologia das células e seu material genético, permitindo análise molecular.

Em estudo anterior de nosso laboratório, não encontramos mutações nos éxons 5 a 8 do gene TP53 pelas técnicas de reação em cadeia da polimerase (PCR) e single strand conformation polymorfism (PCR-SSCP) em lesões de fígado e rim induzidas em modelo de carcinogênese química experimental( ${ }^{(4)}$. Nesse estudo, o DNA não foi extraído de lesões histológicas específicas, de modo que a análise molecular consistiu em um pool de células procedentes tanto de lesões neoplásicas e pré-neoplásicas como dos tecidos normais adjacentes a elas. Assim, não se pode afastar a possibilidade de que a ausência de alterações moleculares tenha resultado de "diluição" do DNA alterado, já que as células neoplásicas e pré-neoplásicas constituem uma população relativamente pequena do tecido analisado, criando condições para resultados falso negativos ${ }^{(14)}$. Para evitar essa fonte de erro, as alterações do genoma devem ser preferencialmente pesquisadas em amostras de células transformadas, procedentes de lesões pré-neoplásicas ou neoplásicas específicas. Uma maneira de fazer isso é pelo uso de MCL.

A experiência relatada na literatura com esse procedimento é animadora. Um estudo de 2001 comparou a microdissecção manual e a MCL em amostras de sete adenocarcinomas colorretais arquivadas em parafina. As amostras microdissecadas foram avaliadas por PCR, SSCP e seqüenciamento. Foram detectadas mutações no éxon 1 do oncogene K-RAS e nos éxons 5 e 7 do TP53 em cinco dos sete casos processados por $\mathrm{MCL}$ e por microdissecção manual. A MCL permitiu genotipagem mais rápida e eficiente, reduzindo o tempo para a análise molecular ${ }^{(6)}$. Estudos clínicos têm utilizado a MCL para avaliar a assinatura molecular de neoplasias ${ }^{(5,13,17)}$. A MCL também pode ser aplicada em modelos experimentais para identificar mutações e alterações da expressão gênica críticas da carcinogênese ${ }^{(8)}$.

O presente estudo descreve as etapas de padronização da MCL para obtenção de segmentos de DNA de lesões tumorais de fígado e rim induzidas em modelo de carcinogênese química experimental(7). Os genes alvo de investigação nesse estudo foram o éxon 8 do TP53 e o gene da ciclofilina. O TP53 é um supressor tumoral e está associado aos processos de proliferação, diferenciação e morte celular ${ }^{(16)}$. Por isso acha-se envolvido de modo importante na oncogênese humana e experimental ${ }^{(11,12)}$. O gene da ciclofilina é constitutivo (house-keeping) do rato; codifica um receptor intracelular da ciclosporina $A$, um potente agente imunossupressor ${ }^{(3)}$.

\section{Objetivos}

Padronizar técnicas de microdissecção e captura a laser, extração de DNA e PCR usando como alvos de investigação o éxon 8 do gene TP53 e o gene da ciclofilina obtidos de neoplasias de fígado e rim fixadas em formalina e incluídas em parafina.

\section{Material e métodos}

\section{Seleção das amostras}

Foram selecionados blocos de parafina com amostras de fígado (sete adenomas e quatro carcinomas) e de rins (cinco carcinomas de células tubulares) de um protocolo de carcinogênese química sistêmica ${ }^{(7)}$. Foram obtidas por microdissecção 26 amostras pareadas de neoplasia e tecido normal adjacente e três amostras somente de tumores.

\section{Processamento histológico do material}

Os fragmentos de fígado e de rim foram fixados por 48 horas em formalina a 10\% tamponada com fosfato de sódio monobásico e fosfato de sódio dibásico anidro, nas proporções de 4 e 6,5 g//(12), lavados em água corrente durante 24 horas e mantidos em álcool a 70\% por até 72 horas. Em seguida, foram submetidos a processador automático de tecidos (Leica EG1160, Alemanha), com desidratação por álcool e diafanização por xilol(12). Os tecidos foram incluídos em parafina a $60^{\circ} \mathrm{C}$ em inclusor automático (Leica EG 1160, Alemanha).

\section{Preparo das lâminas para $M C L$ e extração de DNA}

Foram testados cortes histológicos com três espessuras (4, 5 e $6 \mu \mathrm{m}$ ) obtidos em micrótomo semi-automático (Leica RM 214, Alemanha). Para cada bloco de parafina a ser recortado fez-se assepsia do micrótomo com álcool a 70\%, assim como troca de navalha, do parafilme e das luvas do técnico. Para distensão do corte usou-se banho-maria com água destilada (aproximadamente a $50^{\circ} \mathrm{C}$ ). As lâminas com os cortes histológicos foram mantidas em temperatura am- 
biente overnight para secar e, a seguir, coradas com azul de toluidina (Tabela 1). Atenção especial foi dada à etapa de desidratação durante a técnica de coloração, pois a presença de água no corte histológico impede a adesão adequada do fragmento histológico ao filme termoplástico, dificultando a captura quando a emissão do laser é ativada ${ }^{(2)}$. As lâminas ficaram sem lamínulas de 20 a 30 minutos em temperatura ambiente antes do procedimento de MCL. Cortes histológicos de cada amostra foram corados por hematoxilina e eosina (H-E) para análise morfológica de controle.

\section{Microdissecção e captura a laser}

A MCL foi realizada com o sistema computadorizado Pix Cell II Laser Capture Microdissection (Arcturus, Inc., Califórnia, EUA), que consiste em um emissor de feixes de raio laser e um microscópio ótico invertido acoplados a um sistema de vídeo (Figura 1). O corte histológico deve se localizar no centro da lâmina, visto que ela é fixada ao microscópio por um sistema a vácuo. Um suporte articulado ao microscópio se acopla a um botão plástico transparente que possui um filme termoplástico em sua extremidade denominado cap (CapSureTM Macro LCM Caps LCM 0211, Arcturus Bioscience Mt. View, CA). Esse suporte transporta o cap para uma posição precisa sobre o tecido, alinhando-o à objetiva do microscópio. A imagem de interesse (células isoladas ou grupos celulares) é visualizada no monitor de vídeo, permitindo orientar a dissecção por disparos sucessivos de feixes de laser de alta precisão. A base do microscópio é movida por um joystick para colocar a área de interesse no campo ótico. De acordo com a extensão da área a ser microdissecada, podem-se utilizar três opções de diâmetro do feixe de raio laser (7,15 e $30 \mu \mathrm{m})$. A microdissecção é feita disparando-se a quantidade de tiros necessários para recortar a área de interesse. A captura ocorre por aquecimento do filme termoplástico que se adere ao tecido dissecado. Ao final, o cap é retirado do sistema com um suporte próprio e acoplado a um tubo Ependorff contendo solução para extração do DNA.

Foram microdissecadas 20 amostras com $15 \mu \mathrm{m}$ de diâmetro do feixe de laser e 13 amostras com $30 \mu \mathrm{m}$. Foram dados, em média, 2 mil disparos do laser para cada amostra. Somente as áreas selecionadas foram capturadas pelo filme termoplástico. O restante do tecido (bordas e tecido nãoalvo) permaneceu intacto na lâmina histológica. A morfologia do fragmento transferido foi preservada e pode ser facilmente visualizada em microscopia ótica (Figura 2). Após coletar

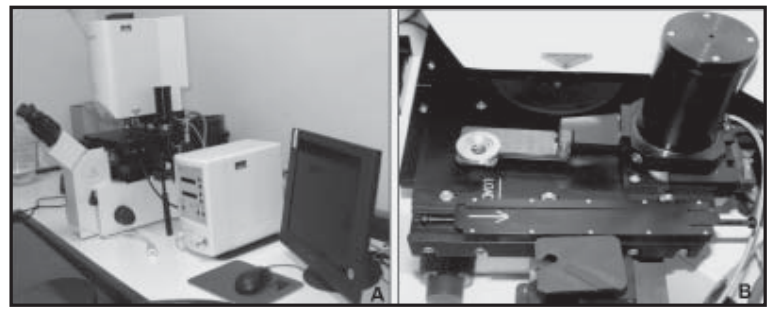

Figura 1 - A: Sistema de microdissecção e captura a laser (MCL), monitor de vídeo, fonte do laser e microscópio mostrando o joystick e o botão que aciona o tiro do laser. B: Suporte para os caps e o braço transportador do cap até a lâmina

Tabela 1 Procedimentos de coloração das amostras para microdissecção e captura a laser

\begin{tabular}{lcc}
\hline Etapas & Soluções & Tempo \\
Desparafinização & Xilol I & 2 min \\
Hidratação & Xilol II & 2 min \\
& Etanol absoluto I & 2 min \\
& Etanol a 95\% & 1 min \\
Coloração & Etanol a 75\% & 1 min \\
Desidratação e diafanização & Água destilada & $30 \mathrm{~s}$ \\
& Azul de toluidina a 0,5\% & Cobrir o corte e lavar em seguida \\
& Etanol a 75\% & $30 \mathrm{~s}$ \\
& Etanol a 95\% & $30 \mathrm{~s}$ \\
& Etanol absoluto II & $30 \mathrm{~s}$ \\
\hline
\end{tabular}




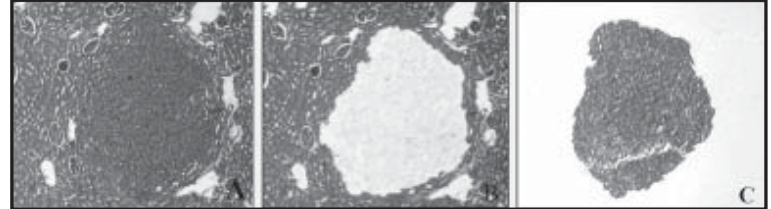

Figura 2 - Microdissecção e captura a laser de um adenocarcinoma renal de células tubulares. A: Posicionamento do adenocarcinoma para MCL; B: Captura apenas do tumor, restando o tecido normal circunjacente; C: Visualização do tumor capturado, com morfologia intacta

as áreas de interesse, o cap foi encaixado em microtubo Eppendorf de $0,5 \mathrm{ml}$ contendo $100 \mu \mathrm{l}$ do tampão de extração (100 mM de Tris pH 8; 50 mM de ácido etilenodiaminotetracético [EDTA] pH 8; e 500 mM de cloreto de sódio [ $\mathrm{NaCl}]$ ), $10 \mu$ de proteinase $\mathrm{K} 10 \mathrm{mg} / \mathrm{ml}$ e $10 \mu \mathrm{l}$ de dodecil sulfato de sódio (SDS), que foi mantido em suporte com gelo até o momento da MCL. O microtubo com o cap foi invertido e agitado vigorosamente para transferir a amostra do cap para o tampão de extração(14). O material foi mantido a $-20^{\circ} \mathrm{C}$ até o momento da extração do DNA.

\section{Procedimentos de extração do DNA}

Para extração do DNA, os tubos invertidos e vedados com parafilme foram aquecidos a $56^{\circ} \mathrm{C}$ por 30 minutos e incubados em banho-maria a $37^{\circ} \mathrm{C}$ overnight. Em seguida foram centrifugados a 14.000 rpm por 1 minuto. O tampão de extração contendo as células microdissecadas foi transferido para um microtubo de $1,5 \mathrm{ml}$, tendo sido adicionados 300 $\mu \mathrm{l}$ de fenol-clorofórmio-álcool isoamílico, na proporção de 25:24:1, e homogeneizado por inversão durante 5 minutos. Centrifugou-se novamente a 14.000 rpm por 15 minutos. $O$ sobrenadante foi transferido para novo tubo, sendo adicionados $300 \mu$ l de clorofórmio-álcool isoamílico (24:1). Após nova centrifugação, transferiu-se o sobrenadante para outro tubo e a precipitação do DNA foi feita pela adição de $500 \mu \mathrm{l}$ de etanol absoluto gelado $\left(-20^{\circ} \mathrm{C}\right)$ e $25 \mu \mathrm{l}$ de acetato de amônio $7,5 \mathrm{M}$, com manutenção a $-80^{\circ} \mathrm{C}$ durante aproximadamente 1 hora. Após nova centrifugação, o etanol absoluto foi descartado e $500 \mu \mathrm{l}$ de etanol a $70 \%$ foram adicionados para lavar e hidratar o DNA. Em seguida, o tubo foi centrifugado e o etanol, descartado. Os tubos foram mantidos invertidos para secar o pellet de DNA por aproximadamente 2 horas. O DNA foi ressuspenso em $20 \mu$ de água ultrapura estéril. A quantificação do DNA das amostras foi realizada em espectrofotômetro Biophotometer Eppendorf.

\section{Padronização da técnica de PCR}

As amplificações do gene da ciclofilina e do éxon 8 do TP53 pela técnica de PCR foram realizadas para confirmar a eficácia da extração do DNA. Para ambos os segmentos gênicos de interesse foi utilizada a técnica de nested-PCR, que consiste em uma segunda reação de amplificação para aumentar o número de cópias do segmento gênico amplificado na primeira reação. As condições para amplificação de cada um dos segmentos gênicos analisados são apresentadas adiante. Todas as reações de PCR foram realizadas em termociclador Peltier Thermal Cycler (M) Research, Waltham, MA) e verificadas em gel de agarose a $2 \%$ corado com brometo de etídio. Como controle negativo das reações, o DNA das amostras foi substituído pela mesma quantidade de água destilada.

Para amplificação do gene da ciclofilina, a PCR inicial (com volume final $50 \mu \mathrm{l}$ ) foi feita com $4 \mu \mathrm{l}$ de DNA, tampão de amplificação (200 mM Tris- $\mathrm{HCl} ; 500 \mathrm{mM} \mathrm{KCl}$ ) diluído $1 \mathrm{X}, 1,5 \mathrm{mM}$ de cloreto de magnésio $\left(\mathrm{MgCl}_{2}\right), 0,4 \mathrm{mM}$ de desorribonuleotídeo trifosfatado (dNTP), 2,5 U de enzima Taq DNA polimerase (Invitrogen, Carlsbad, CA, EUA) e 0,2 $\mu \mathrm{M}$ dos devidos iniciadores: ciclofilina $S$ - ACGCCGCTGTCTCTTTC e ciclofilina A-TCCCTTCTTCACCTTCC (tamanho do amplicon: 440)(1). O perfil de ciclagem utilizado foi $2 \mathrm{~min}$ a $94^{\circ} \mathrm{C}, 33$ ciclos de 45 s a $95^{\circ} \mathrm{C}, 30$ s a $57,7^{\circ} \mathrm{C}$ e 1 min a $72^{\circ} \mathrm{C}$, seguido por extensão de $10 \mathrm{~min}$ a $72^{\circ} \mathrm{C}$. Para a nested-PCR, um mix de volume final de $50 \mu \mathrm{l}$ foi feito contendo $40 \mu \mathrm{l}$ do amplificado da primeira reação, $1 \times$ tampão de amplificação, 1,5 mM de $\mathrm{MgCl}_{2}$, 0,4 mM dNTPs, 2,5 U de enzima Taq DNA polimerase e $0,2 \mu \mathrm{M}$ dos mesmos iniciadores. O perfil de ciclagem utilizado foi o mesmo da primeira reação.

Para amplificação do éxon 8 do gene TP53, a reação inicial (volume final $25 \mu \mathrm{l}$ ) foi feita contendo $4 \mu \mathrm{l}$ de DNA, 1x tampão de amplificação, $3 \mathrm{mM}$ de $\mathrm{MgCl}_{2}$, 0,30 mM dNTPs, $1 \mathrm{U}$ de enzima Taq DNA polimerase e 0,25 $\mu \mathrm{M}$ dos devidos iniciadores: p53.8S - CCCTTGCTCTCTCCTTCCATA e p53.8A -TTGGTACCTTAAGGGTGAAATA (tamanho do amplicon: 102pb). O perfil de ciclagem utilizado foi $5 \mathrm{~min}$ a $94^{\circ} \mathrm{C}, 40$ ciclos de $1 \mathrm{~min}$ a $95^{\circ} \mathrm{C}, 30 \mathrm{~s}$ a $58^{\circ} \mathrm{C}$ e $1 \mathrm{~min}$ e $20 \mathrm{~s}$ a $72^{\circ} \mathrm{C}$, seguido por extensão de $7 \mathrm{~min}$ a $72^{\circ} \mathrm{C}$. Para a nested-PCR, um mix de volume final de $25 \mu \mathrm{l}$ foi feito, contendo 19,66 $\mu \mathrm{l}$ do amplificado da primeira reação, $1 \times$ tampão de amplificação, $3 \mathrm{mM}$ de $\mathrm{MgCl}_{2}$, 0,3 mM dNTPs, $1 \mathrm{U}$ de enzima Taq DNA polimerase e 0,25 $\mu \mathrm{M}$ dos mesmos iniciadores. O perfil de ciclagem utilizado foi o mesmo da primeira reação.

Foram realizadas curvas de volume de amplificado e de concentração de $\mathrm{MgCl}_{2}$ para otimizar a reação. Para a primeira curva escolhemos uma amostra amplificada anteriormente e realizamos a PCR conforme o procedimento descrito anteriormente. Para a nested-PCR foram fornecidas quantidades de 1, 4, 8 e $12 \mu \mathrm{l}$ de amplificados procedentes 
da primeira reação. Os demais reagentes permaneceram nas mesmas concentrações. Para a curva de $\mathrm{MgCl}_{2}$ a primeira reação foi realizada conforme já referido. Na segunda reação, concentrações de tampão, dNTPs, primers e Taq polimerase foram mantidas e o volume de $8 \mu \mathrm{L}$ de amplificado, fixado. As concentrações de $\mathrm{MgCl}_{2}$ foram de $3 \mathrm{mM}$ (concentração da primeira reação) e 4 e $5 \mathrm{mM}$. A análise foi feita em gel de poliacrilamida a $7 \%$ corado com solução de nitrato de prata, que permite maior acuidade na discriminação das bandas.

\section{Resultados}

Os resultados deste estudo são apresentados na Ta-

bela 2. O diâmetro de $15 \mu \mathrm{m}$ do feixe de laser permitiu melhor controle de calibração do equipamento de MCL. A análise por espectrofotometria da quantidade de DNA das amostras obtidas por MCL foi inferior à sensibilidade do aparelho $(<2,5 \mu \mathrm{g} / \mathrm{ml})$. As análises das curvas de volume de amplificado e de concentração de $\mathrm{MgCl}_{2}$ para o éxon 8 do gene TP5 3 indicaram que o volume de $8 \mu \mathrm{l}$ (Figura 3) e a concentração de $5 \mathrm{mM}$ (dados não mostrados) foram os que apresentaram melhores resultados na nested-PCR. No total dos procedimentos executados, $48,3 \%$ das amostras amplificaram para o éxon 8 do gene TP53 e 51,7\% para o gene da ciclofilina (Figura 4). Considerando a amplificação de pelo menos um dos dois segmentos gênicos, obtivemos 79,3\% de amplificação das amostras analisadas.

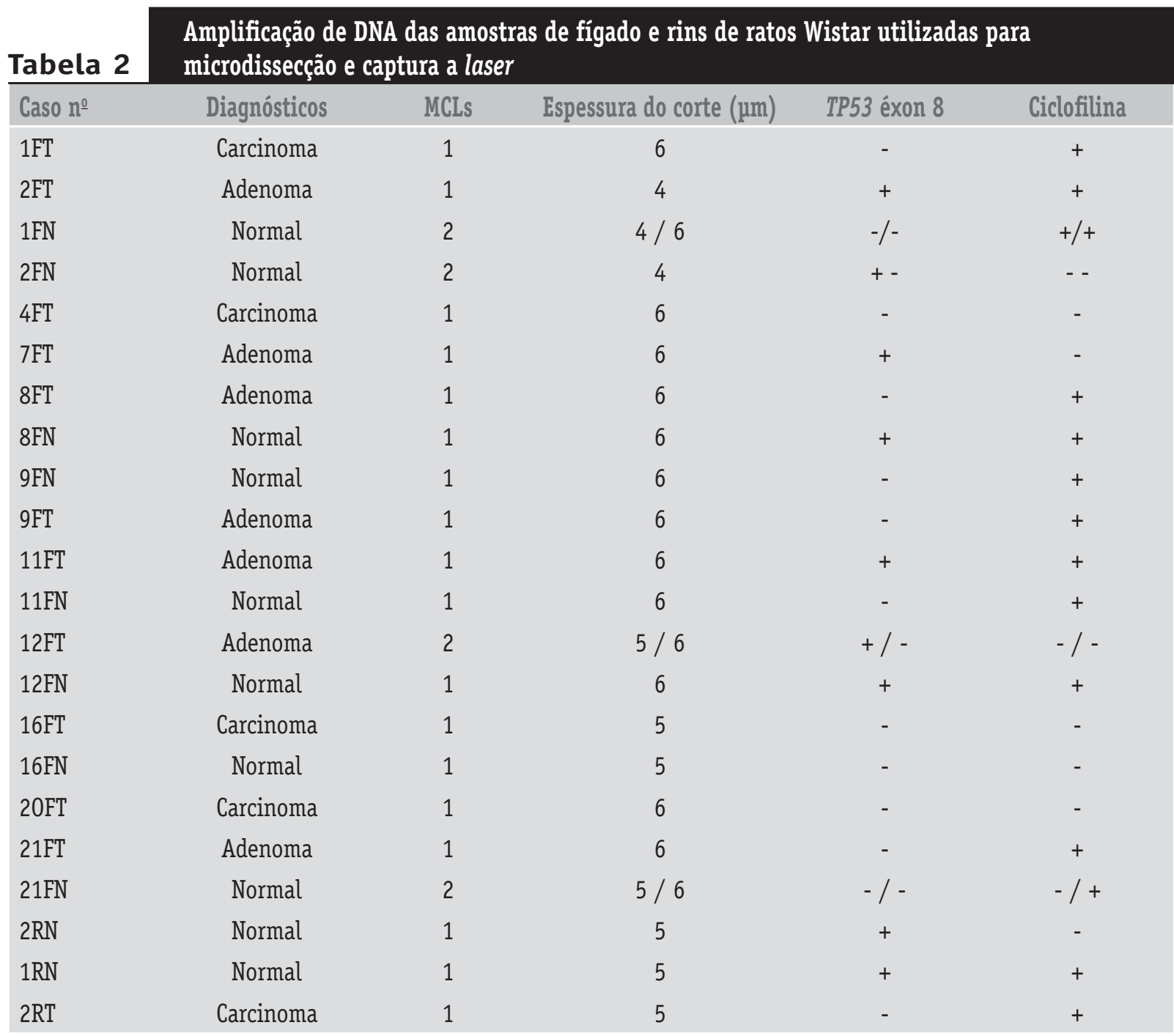




\begin{tabular}{|c|c|c|c|c|c|}
\hline 1RT & Carcinoma & 1 & 5 & + & + \\
\hline 3RT & Carcinoma & 1 & 5 & + & - \\
\hline 3RN & Normal & 1 & 5 & - & - \\
\hline 4RT & Carcinoma & 1 & 5 & - & - \\
\hline 5RT & Carcinoma & 1 & 5 & + & - \\
\hline 5RN & Normal & 1 & 5 & + & \\
\hline 4RN & Normal & 1 & 5 & + & - \\
\hline
\end{tabular}

FT: amostra de fígado tumoral; FN: amostra de fígado normal adjacente ao tumor; RT: amostra de rim tumoral; RN: amostra de rim normal adjacente ao tumor; MCLs: número de microdissecções realizadas para cada amostra.

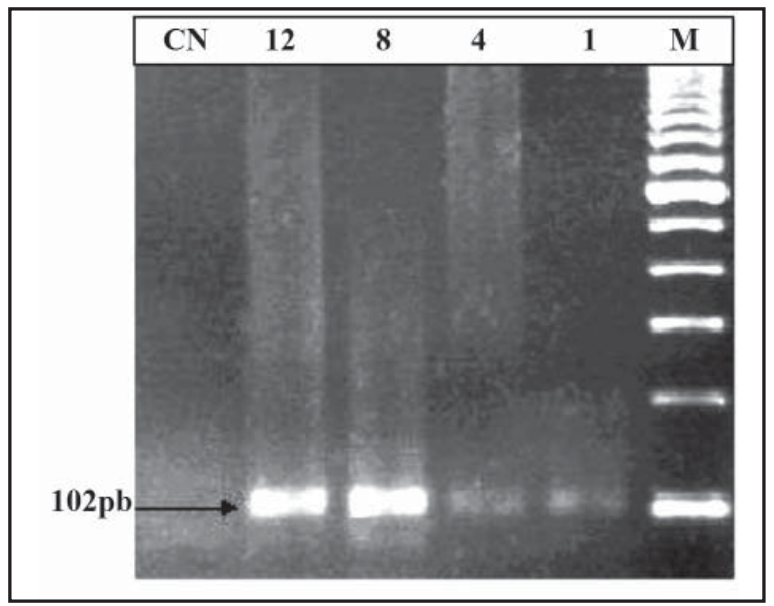

Figura 3 - Gel de agarose a 2\% da amostra 11FT mostrando resultado da nested-PCR para o éxon 8 do gene TP53 com diferentes volumes de amplificado da primeira reação $(1,4,8$ e $12 \mu l)$. $C N=$ controle negativo; $M=$ marcador de $100 \mathrm{pb}$.

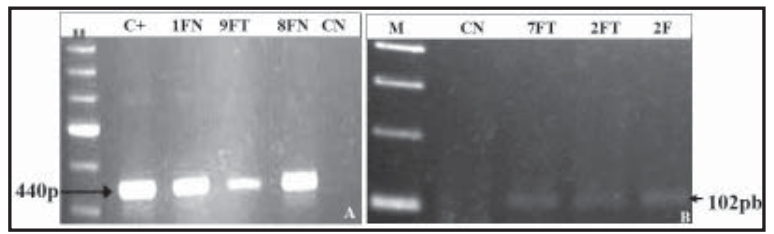

Figura 4 - Géis de agarose $2 \%$ mostrando resultados da nested-PCR para um subgrupo de amostras de fígado: A) gene da ciclofilina. $C_{+}=$controle positivo dessa reação, realizado com amostra não-microdissecada. B) éxon 8 do gene TP53. CN = controle negativo; $M=$ marcador $100 \mathrm{pb}$.

\section{Discussão}

Nossos resultados indicam que, em quase $80 \%$ das amostras, a metodologia utilizada foi bem-sucedida para obtenção de segmentos de DNA de tecidos fixados em formalina tamponada e incluídos em parafina. A amplificação dos segmentos gênicos só foi possível pela utilização da nested-PCR. Essa é uma variante da PCR que possui maior sensibilidade, indicada quando os amplificados obtidos inicialmente não são visualizados em gel de agarose, levando ao risco de resultados falso negativos ${ }^{(15)}$.

O preparo das lâminas com os cortes histológicos possui peculiaridades que são críticas para o sucesso da MCL. Por exemplo, é importante não secar as lâminas em estufa, pois isso acarreta maior aderência do tecido à lâmina, dificultando seu "descolamento" pelo laser e conseqüente captura pelo cap após a microdissecção. Outro fator capaz de interferir no êxito da MCL é a espessura do corte histológico, que pode variar conforme o tecido estudado. No caso de órgãos maciços, como fígado e rim, a espessura de $5 \mu \mathrm{m}$ adotada no presente estudo foi adequada, pois forneceu material genômico suficiente para amplificação. Cortes mais delgados, como $4 \mu \mathrm{m}$, fornecem menor quantidade de material, e cortes mais espessos, como $6 \mu \mathrm{m}$, apesar de fornecerem mais material, mostraram duas dificuldades: não permitiram acurácia na visualização das lesões de interesse e foram mais difíceis de dissecar. A coloração de azul de toluidina foi escolhida por ser procedimento de menor custo e de execução mais rápida do que a $\mathrm{H}-\mathrm{E}$ convencional.

Nossos resultados mostraram que $51,7 \%$ das amostras amplificaram para o gene da ciclofilina e $48,3 \%$ para o éxon 8 do gene TP53. Entretanto, cerca de 50\% das amostras não amplificaram para pelo menos um dos genes. Esse número relativamente alto de não-sucessos pode ser atribuído a diversos fatores, que incluem: a) o esgotamento da suspensão de DNA extraído; b) problemas com o processamento técnico dependentes da duração da fixação do tecido em formalina e ou do tempo de inclusão em parafina, resultando em fragmentação do DNA; c) pouca quantidade de DNA genômico obtido da extração. O insucesso parcial da amplificação do gene house-keeping da ciclofilina também pode ser devido ao longo comprimento de seu amplificado (440 pb), pois, quando o DNA está comprometido pelo processamento do material, como é possível ocorrer em material fixado e incluído em parafina, é desejável que o desenho dos primers envolva amplicons menores que $200 \mathrm{pb}^{(10)}$.

Neste trabalho lidamos com dois fatores limitantes à amplificação gênica: o número relativamente reduzido de células capturadas por MLC e a fragmentação de DNA genômico resultante do processamento histológico dos tecidos. A qualidade e a quantidade do DNA obtido na extração das amostras parafinadas e microdissecadas não podem ser comparadas às conseguidas de tecido fresco e homogêneo em sua composição. Reconhecendo essas limi- 
tações inerentes ao material analisado, utilizamos recursos e procedimentos adequados para a obtenção de seqüências de DNA para análise molecular.

\section{Conclusão}

No conjunto, os resultados indicam que o preparo dos cortes histológicos para MCL e a extração de DNA das lesões foram efetivos, permitindo a amplificação de segmentos genômicos de interesse em quase $80 \%$ das amostras analisadas. A incorporação da técnica de nested-PCR permitiu superar a limitação resultante da escassez de material microdissecado. Esses procedimentos podem ser úteis para pesquisa de mutações gênicas por seqüenciamento direto dos produtos de PCR ou para estudos de expressão gênica por RT-PCR em material arquivado em blocos de parafina ${ }^{(9,10)}$.

\section{Agradecimentos}

O Dr. Fernando Soares viabilizou o treinamento de um dos autores (MLCSO) no laboratório de MCL do Instituto Ludwig para Pesquisa do Câncer, em São Paulo. A Dra. Maria Aparecida Marchesan Rodrigues reviu criticamente o manuscrito. As Dras. Silvia Regina Rogatto e Cláudia Rainho forneceram sugestões inestimáveis para o desenvolvimento deste estudo. Os pós-graduandos Rodrigo Mattos dos Santos, Cristiane Melissa Tomazini e Robson Francisco Carvalho auxiliaram nos procedimentos laboratoriais.

\section{Referências}

1.ALWAYS, S. E. et al. Increased myogenic repressor Id mRNA and protein levels in hindlimb muscles of aged rats. Am J Physiol Regul Integr Comp Physiol, v. 285, p. 4 I I-22, 200 I.

2. ARCTURUS. Laser capture microdissection with the PixCell $\|^{\circledR}$ : training and certification course - Level I. Version I.0. Mountain View, California, 2000. 86p.

3. BEL, E.; BARNES, N. Other pharmacotherapy. Eur Respir Rev, v. I0, n. 69, p. 10-82, 2000

4. CASTELLI, E. C. et al. No mutations found in exons ofTP53, HRAS and K-RAS genes in liver of male Wistar rats submitted to a medium-term chemical carcinogenesis assay. Bras Patol Med Lab, v. 38, p. 175-82, 2002.

5. DENG, W. G. et al. Potential role of p53 mutation in chemical hepatocarcinogenesis of rats. World J Gastroenterol, v. I0, n. I, p. 46-52, 2004.

6. DILLON, D.; ZHENG, K.; COSTA, J. Rapid, efficient genotyping of clinical tumor samples by laser-capture microdissection/ PCR/SSCP. Exp Mol Pathol, v. 70, p. 195-200, 200 I.

7. FRANCHI, C.A. S. Restrição energética e carcinogênese hepática promovida por hexaclorobenzeno (HCB) em ratos. 2005. 68f. Dissertação (Doutorado). Faculdade de Medicina, Universidade Estadual Paulista, Botucatu.

8. FU, Y. et al. Mutation and expression of the p53 gene during chemical hepatocarcinogenesis in F344 rats. Biochim Biophys Acta, v. 1628, p. 40-9, 2003.

9. GREENBLATT, M. S. et al. Mutations in the p53 supressor gene: clues to cancer etiology and molecular pathogenesis. Cancer Res, v. 54, p. 4855-78, 1994.

I0. GREER, C. E.,WHEELER, C. M., MANOS, M. M. PCR amplification from paraffin embedded tissues: sample preparation and the effects of fixation. In: DIEFFENBACH, C.W., DVEKSLER, G.S (eds.). PCR primer, a laboratory manual. Plain view NY: Cold Spring Harbor Lab Press, 1995. Chap. I, p.99-I I 2.

I I. ISHIKAWA, T. et al. DNA repair and cancer: lessons from mutant mouse models. Cancer Sci, v. 95, n. 2, p. I I2-7, 2004.

12. MICHALANY,J. Técnica histológica em anatomia patológica: com instruções para cirurgião, enfermeira e citotécnico. 3. ed. São Paulo: Michalany, 1998.295p.

13. MOURA-GALLO, C. V. et al. TP53 mutation in malignant breast tumors: association with risk factors and clinicalpathological characteristics, including risk of death, in patients from Rio de Janeiro. Rev Bras Epidemiol, v. 7, p. | 67- 75, 2004.

14. NAGAI, H. et al. Characterization of liver-cirrhosis nodules by analysis of gene-expression profiles and patterns of allelic loss.J Hum Genet, v. 49, n. 5, p. 246-55, 2004.

15. SIMONE, N.L. et al. Laser capture microdissection: opening the microscopic frontier to molecular analysis. Trends Genet, v. 16, p. 272-6, 1998 .

16.ZENG, Q.Y.; HANSSON, P.;WANG, X. R. Specific and sensitive detection of the conifer pathogen Gremmeniella abietina by nested PCR. BMC Microbiol, v. 5, n. I, p. 65-94, 2005.

17. YAMASAKI, H. Multistage carcinogenesis: implications for risk estimation. Cancer Metastasis Rev, v. 7, p. 5-18, 1988.

I 8.YANG, F. et al. Laser microdissection and microarray analysis of breast tumors reveal ER-alpha related genes and pathways. Oncogene, v. 25, n. 9, p. 14|3-9, 2006.

19. YAZDI, A. S. et al. Laser-capture microdissection: Applications in routine molecular dematopathology.J Cutan Pathol, v. 31 , n. 7, p. 465, 2004.

\begin{tabular}{l|l} 
& Endereço para correspondência \\
\hline & João Lauro Viana de Camargo \\
Departamento de Patologia da Faculdade de \\
Medicina da Universidade Estadual Paulista (Unesp) \\
Distrito de Rubião Júnior, s/n \\
CEP 18618-000 - Botucatu-SP \\
e-mail: decam@fmb.unesp.br
\end{tabular}

